\title{
Plant Growth Promoting Characteristics in Some Flavobacterium spp. Isolated from Soils of Iran
}

\author{
Ali-Ashraf Soltani (Corresponding author) \\ Department of soil science, college of agriculture, University of Tehran, Karaj, Iran \\ Tel: 98-911-382-3313 E-mail: ali_soltani_t@yahoo.com \\ Kazem Khavazi \\ Soil and Water Research Institute, Karaj, Tehran, Iran \\ E-mail:kkhavazi@yahoo.com \\ Hadi Asadi-Rahmani \\ Soil and Water Research Institute, Karaj, Tehran, Iran \\ E-mail: Asadi_1999@yahoo.com \\ Mahtab Omidvari \\ Department of plant pathology, college of agriculture, University of Tehran, Karaj, Iran \\ Tel: 98-936-906-3324Ｅ-mail: vania_vandad@yahoo.com \\ Payman Abaszadeh Dahaji \\ Department of soil science, college of agriculture, University of Tehran, Karaj, Iran \\ Tel: 98-919-289-5501_E-mail: dahaji@ut.ac.ir \\ Hamed Mirhoseyni \\ Department of Soil Science, University of Shiraz, Shiraz, Iran \\ Tel: 98-913-257-5892_E-mail: lanati2003@yahoo.com
}

\begin{abstract}
Plant growth promoting rhizobacteria (PGPR) is referred to a heterogeneous group of beneficial rhizosphere bacteria that could enhance plant yield through one or more mechanisms. Flavobacterium has been noted as PGPR in almost all review articles. However, there are a few studies regarding plant growth promotion imposed by them. Some of Plant growth promoting characteristics such as Phosphate solubilizing capacity, ability to use of 1-Amino Cyclopropan-1-Carboxylate (ACC) as sole nitrogen source and production of auxin, siderophore, salicylic acid, chitinase and hydrogen cyanide were evaluated in forty-four flavobacteria isolated from rhizosphere of wheat. Results showed that none of the isolates were able to produce siderophore, salicylic acid and chitinase and they were not able to use ACC as well. Determining the siderophore showed that none isolates did not grow on Chrome Azurol S (CAS) Agar medium. The results of this part were further analyzed using CAS Agar Diffusion (CASAD) method, but the results were also negative. HCN production was observed in all isolates, but in lowest limit. Thirty-four isolates were capable to solubilize insoluble inorganic Phosphate (P) sources. The average rate of P-solubilization was $3.54 \mu \mathrm{g} \mathrm{Pml}^{-1}$, ranging from zero to $37.48 \mu \mathrm{gPml}^{-1}$. There was a significant negative correlation $(\mathrm{r}=-0.81 * *)$ between solubilized $\mathrm{P}$ and the final $\mathrm{pH}$ of the growth medium. In this study, all the isolates were able to produce auxin, ranging from 0.27 to $12.03 \mu \mathrm{gml}^{-1}$ averaged by 2.03 . Considering the ability of the isolates to produce auxin and for P-solubilization, it is necessary to evaluate their effect on growth and yield of different crop plants.
\end{abstract}

Keywords: Auxin, Chitinase, Flavobacterium, HCN, PGPR and Siderophore 


\section{Introduction}

The rhizosphere as defined by Boven and Rovira (1999) is a tender zone (about 1-3mm) of soil surrounding a plant root where living organisms are influenced by root vital activities (like compounds exuded by the root and respiration) qualitatively and quantitatively. Wide range of microorganisms lives in this area that their variation and accumulation is influenced by plant type.

Rhizobacteria have been classified into beneficial, deleterious and neutral according to their effect on host (Benizri et al., 2001). Classification of beneficial rhizobacteria to symbiotic and asymbiotic have been done on the base of their physical relationship with plant. The term PGPR was first used by Kloepper and Schroth (1978) and investigation on PGPR have been escalating at an ever increasing rate since then.

PGPR can stimulate plant growth directly as they can improve the supply of nutrients, such as nitrogen (Dobbelaere et al., 2003) and phosphorous (Rashid et al., 2004) or by production of phytohormones (Choong et al., 2003; Stepanova et al., 2008) and ACC-deaminase synthesis (Arshad et al., 2007). Indirectly PGPR can also promote plant development by the suppression of pathogens mediated by different mechanisms such as antibiosis (Milner et al., 1996), iron sequestration by siderophores ( Bar-ness et al., 1992), HCN ( Keremer and Souissi, 2001), vitamin excretion (Streit et al., 1996), and cell wall degrading enzymes like chitinase (Ajit et al., 2006). So plant growth is promoted through reducing or neutralizing pathogen activity.

Azotobacter, Entrobacter, Bacillus, Burkholderia, Azospirillum, Pesudomonas, Acinetobacter, Arthrobacter, Alcaligenes, Serratia, Erwinia and Flavobacterium are some of the common PGPRs. (Sturz and Nowak, 2000; Bloemberg and Lugtenberg, 2001; Mayak et al., 2004). Flavobacterium is related to chlorobia group super phylum, Bacteriodete phylum, Flavobacteria class, Flavobacterials order and Flavobacteriaceae family. These bacteria are isomorphic, baciliform, aerobic and gram-negative. Lack of poly- $\beta$-hydroxybutyrate granules, endospore and fellagelin have been seen in these bacteria (Krieg and Holt, 1984). Plant growth promoting qualities of this bacterium is investigated despite it is plant growth stimulating bacteria. The most important growth promoting qualities like auxin production, the ability of using of ACC as nitrogen source, P-solubilization, siderophore, salicylic acid, chitinase and HCN production of Flavobacterium isolates were evaluated in microbial collection of soil biology department of soil and water institute.

\section{Material and Methods}

\subsection{Isolation of Flavobacterium}

44 isolates of Flavobacterium were isolated from wheat rhizosphere. Fluorescent Pseudomonad, strain PA14 was investigated for auxin, salycilic acid, siderophore, chitinase and HCN production and P-solubilisation and PA25 was evaluated for ACC-deaminase production as control isolate.

\subsection{Quantification of IAA}

Production of IAA was assayed based on the method described by Patten and Glick (2002). Strains were grown at $28^{\circ} \mathrm{C}$ for $48 \mathrm{~h}$ on a rotary shaker in $100 \mathrm{ml}$ flasks containing $50 \mathrm{ml}$ TSB medium. Cells were then collected by centrifugation at $10000 \mathrm{~g}$ for $15 \mathrm{~min}$. Finally $2 \mathrm{ml}$ of salkowsky was added to the supernatant. The absorbance of the pink- auxin complex, was read at $535 \mathrm{~nm}$ in a Spectrophotometer. A standard curve was prepared with auxin dissolved in TSB medium. The quantity of auxin in the culture was expressed as $\mathrm{gml}^{-1}$.

\subsection{ACC-deaminase assay}

The ability of strains to utilize ACC as sole nitrogen source was assayed as described by Amico et al. (2005) with some modifications. The bacteria were cultured first in rich medium (TSB). Stock solution of ammonium sulphate $\left(13.21 \mathrm{~g}\right.$ of $\left(\mathrm{NH}_{4}\right)_{2} \mathrm{SO}_{4}$ in $1000 \mathrm{ml}$ of distilled $\mathrm{H}_{2} \mathrm{O}$ ) and DF salts minimal medium (without nitrogen source) were prepared and sterilized by autoclaving and $3.0 \mathrm{mM}$ solution of ACC (30.33 mg of ACC in $10 \mathrm{ml}$ of distilled $\left.\mathrm{H}_{2} \mathrm{O}\right)$ as the source of nitrogen was also filter-sterilized $(0.2 \mu \mathrm{m}) .300 \mu \mathrm{L}$ of each bacterial culture were added to 50-ml flasks containing $15 \mathrm{ml}$ of sterile DF salts medium (with out nitrogen source). Two hundreds micro liters of $\mathrm{ACC}$ and $\left(\mathrm{NH}_{4}\right)_{2} \mathrm{SO}_{4}$ were added to the flasks. Cultures were incubated at $30^{\circ} \mathrm{C}$ on a rotary shaker at $200 \mathrm{rpm}$ for $48 \mathrm{~h}$. After incubation for $48 \mathrm{~h}$ the density of the culture was measured at $405 \mathrm{~nm}$ and the ratio of density in the culture of DF $+\mathrm{ACC}$ medium and DF+ $\left(\mathrm{NH}_{4}\right)_{2} \mathrm{SO}_{4}$ medium was evaluated.

\subsection{Phosphorous assay}

Sterilized Pikovskaya media (PKV) was poured in to sterilized Petri plates after solidification of media, a pinpoint inoculation of bacterial strains was made on the plates under aseptic conditions. The plates were incubated at $28^{\circ} \mathrm{C}$ for 8 days and observed for colony diameter and diameter of solubilization zone regularly 
during 8 days. Solubilization index was evaluated according to the ratio of the total diameter (colony + halo Zone) and the colony diameter (Rashid et al., 2004).

\subsection{CAS agar assay}

Production of siderophores was determined by the method of Alexander and Zuberer, (1991). Isolates were grown on CAS agar plates. The presence of orange halos was recorded up to 7 days after incubation.

\subsection{CASDA assay}

Siderophore production in CASAD method was determined by the method of Shin et al., (2001). Strains were grown at $28 \mathrm{oc}$ for $48 \mathrm{~h}$ on a rotary shaker in $100 \mathrm{~mL}$ flasks containing $50 \mathrm{~mL}$ succinate medium (succinic acid, 4.0g; $\mathrm{K}_{2} \mathrm{HPO}_{4}, 6.0 \mathrm{~g} ; \mathrm{KH}_{2} \mathrm{PO}, 3.0 \mathrm{~g} ;\left(\mathrm{NH}_{4}\right) \mathrm{SO}_{4}, 1.0 \mathrm{~g} ; \mathrm{MgSO}_{4} .7 \mathrm{H}_{2} \mathrm{O}, 0.2 \mathrm{~g}$; distilled water, $1000 \mathrm{~mL} ; \mathrm{pH}$ : 7.0) Cells were then collected by centrifugation at $10000 \mathrm{~g}$ for $10 \mathrm{~min}$. Punch the CAS medium with cork borer and pour 35 $\mathrm{mL}$ from supernatant to these sinks after absorbing. The equal amount of supernatant should be poured in sinks, read the halo diameter.

\subsection{Production of Salicylic acid (SA)}

Strains were grown at $28^{\circ} \mathrm{C}$ for $48 \mathrm{~h}$ on a rotary shaker in $100 \mathrm{ml}$ flasks containing $50 \mathrm{ml}$ succinate medium. Cells were then collected by centrifugation at $6000 \mathrm{~g}$ for $5 \mathrm{~min}$ and $4 \mathrm{ml}$ of cell free culture was acidified with $1 \mathrm{~N} \mathrm{HCl}$ to adjust the $\mathrm{pH}$ to 2.0 and SA was extracted in $\mathrm{CHCl}_{3}(2 \times 2 \mathrm{ml})$. To the pooled $\mathrm{CHCl}_{3}$ phases, $4 \mathrm{ml}$ of distilled water and $5 \mu \mathrm{l}$ of $2 \mathrm{M} \mathrm{FeCl}_{3}$ were added. The absorbance of the purple iron- SA complex, which was developed in the aqueous phase, was read at $527 \mathrm{~nm}$ in a Spectrophotometer. A standard curve was prepared with SA dissolved in succinate medium. The quantity of SA in the culture was expressed as $\mu \mathrm{gml}^{-1}$ (Meyer et al., 1992).

\subsection{Agar plate assay for chitinase}

Chitinase production was determined in a defined medium composed of $\left(\mathrm{gL}^{-1}\right)$ colloidal chitin (Berger and Reynolds, 1958). It was added to nutrient agar medium. $12 \mathrm{~mL}$ of bacterial suspension was cultured in this medium and incubated for 120 hours in $28^{\circ} \mathrm{C}$. The ability of chitinase production was shown by clear halo around colonies (Robert and Cabib, 1988).

\subsection{Cyanide production}

Hydrogen cyanide $(\mathrm{HCN})$ production from glycine was tested growing the bacteria in $10 \%$ trypic soy agar (TSA) supplemented with glycine $\left(4.4 \mathrm{gL}^{-1}\right)$ and cyanogenesis was revealed using picric acid and $\mathrm{Na}_{2} \mathrm{CO}_{3}(0.5$ and $2 \%$ respectively). Impregnated filter paper fixed to the underside of the Petridis lids. Results were read after five days of culture at $28^{\circ} \mathrm{C}$. A change in filter paper colors from yellow to orange-brown indicated production of HCN.(Yellow (1) limit cyanide production, orange (2) moderate cyanide production, light brown (3) relatively high cyanide production and brown (4) high cyanide production) (Donate-correa et al., 2004).

\section{Results}

44 isolates of Flavobacterium were isolated from wheat rhizosphere were tested for their plant growth promoting qualities. All of the strains could produce auxin. The average amount of auxin was $2.03 \mu \mathrm{gml}^{-1}$ and its extent was changeable between 0.27 to 12.03 . The high auxin activity was recorded for F9 and F32 respectively (Table 1).

None of the isolates produced salicylic acid (Table 1) when, the control isolate, PA14, produced $9.05 \mu \mathrm{gml}^{-1}$ salicylic acid. Any isolate couldn't generate chitinase while the culture media was suitable for responding against chitinase and some of bacteria which were isolated from soil, made a bright halo around themselves (Table 1). None of the isolates could grow on CAS- agar media. CASAD method indicated, none of the isolates could produce siderophore (Table 1).

Any isolate couldn't generate ACC-deaminase (Table 2). F1, F3, F5, F6, F8, F9, F10, F12, F13, F14, F15, F17, F18, F19, F20, F21, F22, F24, F26, F27, F29, F30, F31, F32, F33, F35, F36, F37, F38, F39, F40, F41, F42, and F44 couldn't grow on DF minimal medium.

The result of unsoluble mineral P-solubilisation indicated that 34 isolates had been able to solve unsoluble mineral phosphorous (F1, F3, F4, F5, F6, F7, F8, F9, F10, F11, F12, F13, F14, F15, F16, F17, F18, F19, F20, F22, F23, F24, F28, F29, F30, F33, F34, F36, F37, F38, F39, F40 and F41). The average of solubilisation was $3.54 \mu \mathrm{gml}^{-1}$ and it was ranged from 0 to $37.48 \mu \mathrm{gml}^{-1}$. F11 achieved the highest solubilization activity (37.48 $\left.\mu \mathrm{gml}^{-1}\right)$. 10 isolates (F2, F21, F26, F27, F31, F32, F35, F42, F43 and F44) weren't permitted to solve phosphorous. Some of powerful isolates reduced the $\mathrm{pH}$ of media (5.04-5.60) and some of them increased it (5.63-5.80) in comparison with untreated control $(\mathrm{pH}=5.62)$. $\mathrm{PH}$ alternations was significant $(\mathrm{p}=0.01)$. There 
was a negative significant correlation $(\mathrm{r}=-0.81 * *)$ between $\mathrm{Ca}_{3}\left(\mathrm{PO}_{4}\right)_{2}$ solubilization and $\mathrm{pH}$ (Figure 1). The result of $\mathrm{HCN}$ investigation indicated that all of the isolates could produce little amount of this metabolite (Table 1).

\section{Discussion}

Auxin is the most investigated hormone between plant growth regulators. The most common, best characterized and physiologically most active auxin in plant is indole-3-acetic acid (IAA). IAA is known to stimulate both a rapid response (e.g. increased cell elongation) and a long-term response (e.g. cell division and differentiation) in plants (Ahmad et al., 2005). In this investigation, all Flavobacterium isolates have been able to produce IAA. Asghar et al. (2004) showed, $\mathrm{S}_{58}$ and $\mathrm{S}_{89}$ which were related to Flavobacterium genus could beget IAA. The amount of IAA was $24.03 \mu \mathrm{gml}^{-1} \& 2.27 \mu \mathrm{gml}^{-1}$ for S58 and $24.6 \& 4.6 \mu \mathrm{gml}^{-1}$ for S89 in presence and absence of tryptophan, respectively. In the other research, Cattelan et al, (1999) reported, $\mathrm{GW}_{2103}$ and $\mathrm{LC}_{1118}$ isolates of Flavobacterium indologenes had the ability of IAA production. IAA production by PGPRs is different. Ahmad et al. (2005) indicated that the amplitude of IAA in different densities of tryptophan was changeable between 5.32- $5.34 \mu \mathrm{gml}^{-1}$. The extent of IAA in Flavobacterium was changeable and it was enranged from 0.27 to 12.03 $\mu \mathrm{gml}^{-1}$ in this research.

P-solubilizing microorganisms (PSM) involve different character of microorganisms which turn insoluble organic compounds of phosphorous to soluble form (Raju and Reddy, 1999; Sundara et al., 2002). Bacillus and pseudomonas have been the most important P-solvent bacteria (Rashid et al., 2004; Bar-Yosef et al., 1999). Rashid et al, (2004) have shown that 10 isolates of different bacteria which were selected from rice rhizosphere, could solve $\mathrm{Ca}_{3}\left(\mathrm{Po}_{4}\right)_{2}$ in pikovskaya medium. The results indicated 10 isolates couldn't solve $\mathrm{Ca}_{3}\left(\mathrm{Po}_{4}\right)_{2}$ between 49 isolates. Cattelan et al, (1999) have shown that $\mathrm{GW}_{2103}$ and $\mathrm{LC}_{1118}$ isolates of $F$. indologenes couldn't solve it too. Remaining isolates had the low ability to solve it in this research. The highest solvability was $37.48 \mu \mathrm{gml}^{-1}$ for F11.

In addition to the well-characterized mechanisms, such as auxin production and siderophore synthesis, that are employed by PGPR, it was recently proposed that many PGPR may stimulate plant growth through the activity of the enzyme 1-aminocyclopropane-1-carboxylate (ACC) deaminase. Some bacteria degrade ACC to ammonia and $\alpha$-ketobutyrate through ACC deaminase and finally it reduces ethylene (Penrose and Glick, 2003). Recent researches showed that some of pseudomonas could produce ACC deaminase (Safronova et al., 2006). Belimov et al. 2005 presented that different isolates of Variovorax paradoxus had the ability to make ACC deaminase but $\mathrm{AY}_{197006}$ and $\mathrm{AY}_{197009}$ isolates of Flavobacterium were unable to produce it. Cattelan et al. (1999) exhibited, $\mathrm{GW}_{2103}$ isolate of $F$. indologenes were unable to produce ACC deaminase and $\mathrm{LC}_{1118}$ isolate wasn't investigated due to its lack of growth. The result of our research demonstrated that no Flavobacterium isolate could make ACC deaminase too.

Siderophores are low-molecular-weight molecules that are secreted by many microorganisms in iron shortage condition. O'sullivan and O'Gara. (1992) revealed that many isolates of P.fluorescens have the ability of making siderophore. Belimov et al. (2005) reported, AY 197010 isolate of Pseudomonas and AY 197006 and AY 197009 isolates of Flavobacterium could manufacture siderophore. In this research none of the isolates could grow on CAS-Agar medium. Probabely HDTMA (Hexadecyl trimethyl ammonium bromide) toxicity cause growth insufficiency (Sung et al., 2001). The result of CASAD method have shown, any isolate couldn't make siderophore. Cattelan et al. (1999) reported, there was negligible production of siderophore by $\mathrm{LC}_{1118}$ and $\mathrm{GW}_{2103}$ of $F$. indologenes.

PGPR also activate plant defense resulting in systemic protection against plant pathogens, a phenomenon termed induced systemic resistance (ISR). Salicylic acid produced by PGPR in rhizosphere may be involved in ISR (Maurhofer et al., 1998). SA production by $\mathrm{WC}_{374}, \mathrm{WCS}_{417 \mathrm{r}}$ (Leeman et al.,1996) and CHAO (Maurhofer et al., 1994), P.fluorescens and also $7 \mathrm{NSK}_{2}$ isolate of P.aeruginosa (Demeyer and Hofte, 1997) was reported. Any Flavobacterium isolate could not produce SA in our study.

Chitinase activity is reported in broad-spectrum bacteria (Robert and Cabib, 1988; Neiendam-nielsen et al., 1998; Ajit et al., 2006). It has been reviwed by many researches that P.fluorescens could secrete chitinase as lytic enzyme (Nagarajkumar et al., 2004; Ajit et al., 2006; Saikiar et al., 2005). Disability of chitinase production is reported in some bacteria. O'brien et al. 1987 reported P.aeruginosa and P.putida disabled to make chitinase. $\mathrm{LC}_{1118}$ and $\mathrm{GW}_{2103}$ isolates of $F$. indologenes couldn't generate chitinase too (Cattelan et al., 1999). In this investigation, no Flavobacterium isolate produce chitinase.

Many different bacteria could produce HCN which is toxic for fungi (Blumer and Hass, 2000). HCN production by P.fluoresens, P.aeruginosa and Chromobacterium uiolaceum was reported by many researchers (Seddiqui et al., 2003). Some of Rhizobium isolates were introduced as HCN producers by Antoun et al. (1998). Any isolate couldn't generate $\mathrm{HCN}$ in this study. Cattelan et al. 1999 indicated that $\mathrm{LC}_{1118}$ and $\mathrm{GW}_{2103}$ isolates of $F$. 
indologenes weren't able to produce HCN. The investigation of these Flavobacterium isolates impression on plant growth factors is suggested according to their auxin production and mineral phosphorous solubilization ability.

\section{Acknowledgements}

The authors are grateful to Rouhallah Sharifi, PhD student of plant pathology, department of Bicontrol in Tehran University.

\section{References}

Ahmad, F., Ahmad, L. \& Saghir, M. (2005). Indol acetic acid production by the indogenous isolate of Azotobacter and Pseudomonas fluorescens in the presence and absence of Tryptophan, Turk. J. Biol. 29:29-34.

Ajit, N.S., Verma, R. \& Shanmugan, V. (2006). Extracellular chitinase of fluorescent pseudomonas antifungal to Fusarium oxysporum f.sp.dianti causing carnation wilt. Curr. Microbiol, 52:310-316.

Alexander, D.B. \& Zuberer, D.A. (1991). Use of chrome azurol S reagents to evaluate siderophore production by rhizosphere bacteria. Biol. Fertil. Soils, 12: 39-45.

Amico, E.D., Cavalca, L. \& Andreoni, V. (2005). Analysis of rhizobacterial communities in perennial Graminaceae from polluted water meadow soil, and screening of metal-resistant, potentially plant growth-promoting bacteria. FEMS Microbiol. Ecol, 52: 153-162.

Antoun, H., Beauchamp, C.J., Goussard, N., Chabot, R. \& Lalande, R. (1998). Potential of Rhizobium and Bradyrhizobium species as a plant growth promoting rhizobacteria on non legumes. Plant Soil, 204: 57-67.

Arshad, M., Saleem, M. \& Hussain, S. (2007). Perspectives of bacterial ACC deaminase in phytoremediation. Tren. Biotech, 25(8): 356-361.

Asghar, H.N., Zaeir, Z.A. \& Arshad, M. (2004). Screening rhizobacteria for improving the growth, yield and oil content of canola (Brassica napus L.). Aust. J.Agric. Res, 55:187-194.

Bar-ness, E., Hadar, Y., Chen, Y., Shanzer, A. \& Libman, J. (1992). Iron uptake by plants form microbial siderophores. Plant Physiol, 99: 1329-1335.

Bar-Yosef, B., Rogers, R.D., Wolfram, J.H. \& Richman, E. (1999). Pseudomonas cepacia-mediated rock phosphate solubilization in kaolinite and montmorillonit suspensions. Soil Sci. Soc. Am. J, 63: 1703-1708.

Belimov, A.A., Hontzeas, N., Safronova, V.I., Demchinskaya, S.V., Piluzza, G., Bulitta, S. \& Glick, B.R. (2005). Cadmium-tolerant plant growth-promoting bacteria associated with the roots of Indian mustard (Brassica juncea L. czern.). Soil Biol. Biochem, 37: 241-250.

Benizri, E., Baudoin, E. and Guckert, A. (2001). Root colonization by inoculated plant growth-promoting rhizobacteria. Biocon. Sci. Tech, 11: 557-574.

Berger, L.R. \& Reynolds, D.M. (1958). The chitinase system of a strain of Streptomyces griseus. Biochem. Biophys. Acta, 29: 522-534.

Bloemberg, G.V. \& Lugtenberg, B.J.J. (2001). Molecular basis of plant growth promotion and biocontrol by rhizobacteria., Curr. Opin. Plant Biol, 4: 343-350.

Blumer, C. \& Hass, D. (2000). Mechanism, regulation, and ecological role of bacterial cyanide biosenthesis. Arch. Microbiol, 173(3): 170-177.

Boven, G.D. \& Rovira, A.D. (1999). The rhizosphere and its management to improve plant growth. Adv. Agron, 66: 1-102.

Cattelan, A.J., Hartel, P.G. \& Fuhrmunn, J.J. (1999). Screening for plant growth-promoting rhizobacteria to promote early soybean growth. Soil. Sci. Soc. Am. J, 63: 1670-1680.

Choong, M.R., Mohamed, A.F., Chia-Hui, H., Munagala, S.R., Hun-Yun, W. \& Puul, W.P. (2003). Bacterial volatiles promote growth in Arabidopsis. Plant Biol, 100:4927-4932.

De-Meyer, G. \& Hofte, M. (1997). Salicylic acid produced by the rhizobacterium Pseudomonas aeruginosa 7NKS2 induces resistance to leaf infection by Botrytis conerea on bean. Phytopathology, 87: 588-593.

Dobbelaere, S., Vanderleyden, J. \& Okon, Y. (2003). Plant growth-promoting effects of diazotrophs in the rhizosphere. Crit. Rev. Plant Sci, 22(2): 107-149. 
Donate-Correa, J., Leon-Barrios, M. \& Perez-Galdona, R. (2004). Screening for plant growth-promoting rhizobacteria in Chamaecytisus proliferus (tagasaste), a forage tree-shrub legume endemic to the Canary Island. Plant Soil, 266: 261-272.

Keremer, R.J. \& Souissi, T. (2001). Cyanide production by rhizobacteria and potential for suppression of weed seedling growth. Curr. Microbiol, 43(3): 182-186.

Kloepper, J.W. \&Schroth, M.N. (1978). Plant growth-promoting rhizobacteria on radishes. Proceeding of the International Conference on Plant Pathogenic Bacteria, 2: 879-882.

Krieg, N.R., Holt, J.G. \& Williams, H.J.H. (1984). Bergeys Manual of Systematic Bacteriology, Vol I, 9th ed.964p.

Leeman, M., Den-ouden, F.M., Van-Pelt, J.A., Dirkx, F.P.M., Steijl, H., Bakker, P.A.H.M. \& Schippers, B. (1996). Iron availibility affects induction of systemic resistance to Fusarium wilt of radish by Pseudomonas fluorescens. Phytopathology, 86: 149-155.

Maurhofer, M., Hase, C., Meuwly, P., Metraux, J.P. \& Defago, G. (1994). Induction of systemic resistance of tobacco to tobacco necrosis virus by the root-colonizeing Pseudomonas fluorescens strain CHAO: influence of the gacA gene and of pyoverdine production. Phytopathology, 88: 139-146.

Maurhofer, M., Reimmann, C., Schmidli-sacherer, P., Heeb, S., Haas, D. \& Defago, G. (1998). Salicylic acid biosynthetic genes expressed in Pseudomonas fluorescens strain P3 improve the induction of system resistance in tobacco against tobacco necrosis virus. Phytopathology, 88: 678-684.

Mayak, S., Tirosh, T. \&Glick, B.R. (2004). Plant growth-promoting bacteria confer resistance in tomato plants to salt stress. Plant Physiol. Biochem, 42:565-572.

Meyer, J.M., Azelvander, P. \& Georges, C. (1992). Iron metabolism in Pseudomonas. Salicylic acid, a siderophore of Pseudomonas fluorescens CHAO. Biofactors, 4: 23-27.

Milner, J.L., SiloSuh, L., Lee, J.C., He, H., Clardy, J. \& Handelsman, L. (1996). Produiction of kanosamine by Bacillus cereus UW85. Appl. Environ. Microbiol, 62:3061-3065.

Nagarajkumar, M., Bhaskaran, R. \& Velazhahan, R. (2004). Involvement of secondary metabolities and extracellular lytic enzymes produced by Pseudomonas fluorescens in inhibition of Rhizoctonia solani, the rice, sheath blight pathogen. Microbiol. Res, 159: 73-81.

Neiendam-Nielsen, M., Sørensen, J., Fels, J. \& Pedersen, H.C. (1998). Secondary metaboliteand endochitinase-dependent antagonism toward plant-pathogenic microfungi of Pseudomonas fluorescens isolates from sugar beet rhizosphere. Appl. Environ. Microbial, 64:3563-3569.

O’Brien, M. \& Colwell, R. (1987). A Rapid Test for Chitinase activity that uses

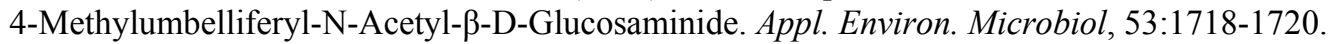

O'Sullivan, D.J. \& O'Gara, F. (1992). Traits of Pseudomonas fluorescens spp. involved in suppression of plant root pathogens. Microbiol. Rev, 56: 662-676.

Patten, C. \& Glick, B. (2002). Role of Pseudomonas putida indole acetic acid in development of the host plant root system. Appl. Environ. Microbiol, 3795-3801.

Penrose, M. \& Glick, R. (2003). Methods for isolating and characterizing ACC deaminase-containing plant growth-promoting rhizobacteria. Physiol. Plant, 118: 10-15.

Raju, R.A. \& Reddy, M.N. (1999). Effect of rock phosphate amended with phosphate solubilizing bacteria and farmyard manure in wetland (Oryza sativa). Ind.J. Agri. Sci, 69: 451-453.

Rashid, M., Khalil, S., Ayub, N., Alam, S. \& Latif, F. (2004). Organic Acids productions solubilization by phosphate solubilizing microorganisms (PSM) under in vitro conditions. Pak. J. Biol. Sci, 7: 187-196.

Roberts, W.K. \& Selitrennikoff, C.P. (1988). plant and bacterial chitinases differ in antifungal activity. J. Gen. Microbiol, 134: 169-176.

Safronova, V.I., Stepanok, V.V., Engqvist, G.L., Alekseyev, Y.V. \& Belimov, A.A. (2006). Root-associated bacteria containing 1-aminocyclopropane-1-carboxylate deaminase improve growth and nutrient uptake by pea genotypes cultivated in cadmium supplemented soil. Biol. Fret. Soils, 42:267-272.

Saikiar, R., Singh, B., Kumar, R. \& Arora, D. (2005). Detection of pathogenesis-related proteins-chitinase and $\beta-1,3$-glucanse in induced chickpea. Curr. Sci, 89: 659-663. 
Shin, S.H., Yong, L., Lee, S.E., Yang, W. \& Rhee, J.H.N. (2001). CAS agar diffusion assay for the measurement of siderophores in biological fluids. J. Microbiol. Meth, 44:89-95.

Siddiqui, I.A., Shaukat, S.S., Khan, G.H. \& Ali, N.I. (2003). Supperssion of Meloidogyne javanica by Pseudomonas aeruginosa IE-6S+ in tomato: the influence of $\mathrm{NaCl}$, oxygen and iron level. Soil.Biol.Biochem, 35:1625-1634.

Stepanova, A.N, Robertson-Hoyt, J., Yun, J., Benavente, L.M., Xie, D.Y., Dolezal, K., Jurgens, S.G. \& Alonso, J.M. (2008). TAA1-mediated auxin biosenthesis is essential for hormone crosstalk and plant development. Cell. 133:177-191.

Streit, W.R., Joseph, C.M. \& Phillips, D.A. (1996). Biotin and other water-soluble vitamins are key growth factors for alfalfa root colonization by Rhizobium meliloti 1021. Mol. Plant-Microbe Interac, 5: 330-338.

Sturz, A.V. \& Nowak, J. (2000). Endophytic communities of rhizobacteria and the strategies required to create yield enhancing associations with crops. Appl. Soil Ecol, 15: 183-190.

Sundara, B., Natarajan, V. \& Hari, K. (2002). Influence of phosphorus solubilizing bacteria on the changes in soil available phosphorus and sugarcane and sugar yields. Field Crop. Res, 77:43-49.

Sung, H.S., Yong, L., Shee, E. \& Nam, W.Y. (2001). CAS agar diffusion assay for the measurement of siderophores in biological fluids. J. Microbial. Methods, 44:89-95. 
Table 1. PGP qualities in studied isolates

\begin{tabular}{|c|c|c|c|c|c|c|c|c|}
\hline isolate & chitinase & $\begin{array}{l}\text { siderophore } \\
\text { CASAD } \\
(\mathrm{mM})\end{array}$ & $\begin{array}{c}\text { siderophore } \\
\text { CAS } \\
\text { (halo colony }^{-1} \text { ) }\end{array}$ & $\underset{\left(\mu \mathrm{gmL}^{-1}\right)}{\mathrm{SA}}$ & $\begin{array}{l}\mathrm{DF}+\mathrm{ACC} \\
\mathrm{DF}+\mathrm{A} . \mathrm{S} .\end{array}$ & $\begin{array}{c}\text { Phosphate } \\
\text { solubilization } \\
\left(\mu \mathrm{gmL}^{-1}\right) \\
\text { and } \mathrm{pH}\end{array}$ & $\underset{\left(\mu \mathrm{gmL}^{-1}\right)}{\operatorname{auxin}}$ & $\mathrm{HCN}$ \\
\hline F1 & - & - & - & - & - & $1 / 24,5 / 64 *$ NOPQ & 1/10KLMNOP & 1 \\
\hline F2 & - & - & - & - & $0 / 10$ & $0,5 / 60 \mathrm{~T}$ & 0/50OPQR & 1 \\
\hline F3 & - & - & - & - & - & $4 / 26,5 / 58 \mathrm{FGH}$ & 0/57NOPQR & 1 \\
\hline $\mathrm{F} 4$ & - & - & - & - & $0 / 35$ & $3 / 85,5 / 64 \mathrm{HI}$ & 0/53NOPQR & 1 \\
\hline F5 & - & - & - & - & - & $.62,5 / 65 \mathrm{RST}$ & 0/43PQR & 1 \\
\hline F6 & - & - & - & - & - & $3 / 64,5 / 59 \mathrm{I}$ & 1/17KLMNO & 1 \\
\hline F7 & - & - & - & - & $0 / 24$ & $6 / 28,5 / 36 \mathrm{E}$ & $5 / 17 \mathrm{E}$ & 1 \\
\hline F8 & - & - & - & - & - & $4 / 67,5 / 67 \mathrm{~F}$ & 0/80LMNOPQR & 1 \\
\hline F9 & - & - & - & - & - & $0 / 83,5 / 62 \mathrm{PQRS}$ & $12 / 03 \mathrm{~A}$ & 1 \\
\hline F10 & - & - & - & - & - & $7 / 15,5 / 45 \mathrm{D}$ & $3 / 10 \mathrm{G}$ & 1 \\
\hline F11 & - & - & - & - & $0 / 26$ & $37 / 48,5 / 04 \mathrm{~A}$ & 0/50OPQR & 1 \\
\hline F12 & - & - & - & - & - & 0/76, 5/63QRS & 1/17KLMNO & 1 \\
\hline F13 & - & - & - & - & - & $1 / 79,5 / 63 \mathrm{KLMN}$ & 0/83LMNOPQR & 1 \\
\hline F14 & - & - & - & - & - & $1 / 11,5 / 71 \mathrm{OPQR}$ & 1/10KLMNOP & 1 \\
\hline F15 & - & - & - & - & - & $3 / 78,5 / 63 \mathrm{HI}$ & $3 / 93 \mathrm{~F}$ & 1 \\
\hline F16 & - & - & - & - & $0 / 18$ & $1 / 17,5 / 60 \mathrm{OPQR}$ & $2 / 47 \mathrm{H}$ & 1 \\
\hline F17 & - & - & - & - & - & $4 / 54,5 / 59 \mathrm{FG}$ & 0/63MNOPQR & 1 \\
\hline F18 & - & - & - & - & - & $9 / 62,5 / 52 \mathrm{C}$ & $2 / 33 \mathrm{HI}$ & 1 \\
\hline F19 & - & - & - & - & - & $3 / 03,5 / 54 \mathrm{~J}$ & $3 / 13 \mathrm{G}$ & 1 \\
\hline $\mathrm{F} 20$ & - & - & - & - & - & $16 / 75,5 / 19 \mathrm{~B}$ & $6 / 97 \mathrm{C}$ & 1 \\
\hline $\mathrm{F} 21$ & - & - & - & - & - & $0,5 / 60 \mathrm{~T}$ & $8 / 83 B$ & 1 \\
\hline F22 & - & - & - & - & - & $6 / 46,5 / 42 \mathrm{E}$ & $3 / 20 \mathrm{G}$ & 1 \\
\hline F23 & - & - & - & - & $0 / 27$ & $1 / 86,5 / 63 \mathrm{KLM}$ & 0/40QR & 1 \\
\hline $\mathrm{F} 24$ & - & - & - & - & - & $3 / 71,5 / 55 \mathrm{HI}$ & $1 / 20 \mathrm{KLMN}$ & 1 \\
\hline F25 & - & - & - & - & $0 / 07$ & $1 / 86,5 / 72 \mathrm{KLM}$ & $1 / 87 \mathrm{IJ}$ & 1 \\
\hline F26 & - & - & - & - & - & $0,5 / 60 \mathrm{~T}$ & $1 / 40 \mathrm{JKL}$ & 1 \\
\hline $\mathrm{F} 27$ & - & - & - & - & - & $0,5 / 60 \mathrm{~T}$ & 0/37QR & 1 \\
\hline F28 & - & - & - & - & $0 / 19$ & 1/38, 5/57MNOP & 0/47PQR & 1 \\
\hline F29 & - & - & - & - & - & $2 / 13,5 / 80 \mathrm{~K}$ & $6 / 10 \mathrm{D}$ & 1 \\
\hline $\mathrm{F} 30$ & - & - & - & - & - & $1 / 99,5 / 63 \mathrm{KL}$ & 0/47PQR & 1 \\
\hline $\mathrm{F} 31$ & - & - & - & - & - & $0,5 / 60 \mathrm{~T}$ & 0/67MNOPQR & 1 \\
\hline $\mathrm{F} 32$ & - & - & - & - & - & $0,5 / 60 \mathrm{~T}$ & $0 / 27 R$ & 1 \\
\hline F33 & - & - & - & - & - & $0 / 07,5 / 63 \mathrm{~T}$ & 0/57NOPQR & 1 \\
\hline F34 & - & - & - & - & $0 / 44$ & $4 / 46,5 / 47 \mathrm{E}$ & $4 / 33 \mathrm{~F}$ & 1 \\
\hline F35 & - & - & - & - & - & $0,5 / 60 \mathrm{~T}$ & 0/37QR & 1 \\
\hline F36 & - & - & - & - & - & $2 / 34,5 / 78 \mathrm{~K}$ & 0/33QR & 1 \\
\hline F37 & - & - & - & - & - & $3 / 99,5 / 82 \mathrm{GHI}$ & 0/60MNOPQR & 1 \\
\hline F38 & - & - & - & - & - & $1 / 45,5 / 70 \mathrm{LMNO}$ & 0/33QR & 1 \\
\hline F39 & - & - & - & - & - & $0 / 62,5 / 70 \mathrm{RST}$ & 0/60MNOPQR & 1 \\
\hline $\mathrm{F} 40$ & - & - & - & - & - & $0 / 48,5 / 59 \mathrm{ST}$ & $1 / 27 \mathrm{KLM}$ & 1 \\
\hline F41 & - & - & - & - & - & $1 / 45,5 / 75 \mathrm{LMNO}$ & 1/03KLMNOPQ & 1 \\
\hline F42 & - & - & - & - & - & $0,5 / 60 \mathrm{~T}$ & 0/70MNOPQR & 1 \\
\hline F43 & - & - & - & - & - & $0,5 / 60 \mathrm{~T}$ & $4 / 00 \mathrm{~F}$ & 1 \\
\hline F44 & - & - & - & - & $0 / 15$ & $0,5 / 60 \mathrm{~T}$ & 1/63JK & 1 \\
\hline PA14 & - & $0 / 92$ & $0 / 17$ & $9 / 05$ & $0 / 10$ & $362 / 34,3 / 26$ & $2 / 46$ & 5 \\
\hline
\end{tabular}

- No production of metabolite

*From left direction, the first number is related to phosphorous solubilization and the second number is related to $\mathrm{pH}$.

The averages containing same letter don't have significant difference in each column. 
Table 2. Growth comparison of isolates in DF, DF containing ACC and DF containing Ammonium sulfate

\begin{tabular}{|c|c|c|c|c|}
\hline \multirow{2}{*}{ isolate } & \multicolumn{3}{|c|}{ Different medium absorbance in $405 \mathrm{~nm}$} & \multirow[b]{2}{*}{$\mathrm{DF}+\mathrm{ACC}$} \\
\hline & $\mathrm{DF}+\mathrm{A} . \mathrm{S}$. & $\mathrm{DF}+\mathrm{ACC}$ & $\mathrm{DF}$ & \\
\hline $\mathrm{F}_{1}$ & * & * & * & * \\
\hline $\mathrm{F}_{2}$ & 0.16 & 0.02 & 0 & 0.10 \\
\hline $\mathrm{F}_{3}$ & $*$ & $*$ & $*$ & $*$ \\
\hline $\mathrm{F}_{4}$ & 0.15 & 0.05 & 0.02 & 0.35 \\
\hline $\mathrm{F}_{5}$ & $*$ & $*$ & * & $*$ \\
\hline $\mathrm{F}_{6}$ & $*$ & $*$ & $*$ & $*$ \\
\hline $\mathrm{F}_{7}$ & 0.16 & 0.04 & 0.02 & 0.24 \\
\hline $\mathrm{F}_{8}$ & $*$ & $*$ & * & $*$ \\
\hline $\mathrm{F}_{9}$ & $*$ & * & * & $*$ \\
\hline $\mathrm{F}_{10}$ & $*$ & * & $*$ & $*$ \\
\hline $\mathrm{F}_{11}$ & 0.23 & 0.06 & 0.06 & 0.26 \\
\hline$F_{12}$ & $*$ & * & $*$ & $*$ \\
\hline$F_{13}$ & $*$ & $*$ & $*$ & $*$ \\
\hline $\mathrm{F}_{14}$ & $*$ & $*$ & $*$ & $*$ \\
\hline $\mathrm{F}_{15}$ & $*$ & $*$ & $*$ & $*$ \\
\hline $\mathrm{F}_{16}$ & 0.17 & 0.03 & 0.03 & 0.18 \\
\hline$F_{17}$ & $*$ & $*$ & * & $*$ \\
\hline $\mathrm{F}_{18}$ & $*$ & $*$ & $*$ & $*$ \\
\hline $\mathrm{F}_{19}$ & $*$ & $*$ & * & $*$ \\
\hline $\mathrm{F}_{20}$ & $*$ & $*$ & $*$ & $*$ \\
\hline $\mathrm{F}_{21}$ & * & $*$ & * & $*$ \\
\hline $\mathrm{F}_{22}$ & $*$ & $*$ & $*$ & $*$ \\
\hline $\mathrm{F}_{23}$ & 0.15 & 0.04 & 0.01 & 0.27 \\
\hline $\mathrm{F}_{24}$ & $*$ & $*$ & $*$ & $*$ \\
\hline $\mathrm{F}_{25}$ & 0.34 & 0.03 & 0.16 & 0.07 \\
\hline $\mathrm{F}_{26}$ & $*$ & $*$ & $*$ & $*$ \\
\hline $\mathrm{F}_{27}$ & $*$ & $*$ & $*$ & $*$ \\
\hline $\mathrm{F}_{28}$ & 0.16 & 0.03 & 0.01 & 0.19 \\
\hline $\mathrm{F}_{29}$ & $*$ & $*$ & $*$ & $*$ \\
\hline $\mathrm{F}_{30}$ & $*$ & * & * & $*$ \\
\hline $\mathrm{F}_{31}$ & $*$ & $*$ & $*$ & $*$ \\
\hline $\mathrm{F}_{32}$ & * & $*$ & * & $*$ \\
\hline $\mathrm{F}_{33}$ & $*$ & $*$ & $*$ & $*$ \\
\hline $\mathrm{F}_{34}$ & 0.20 & 0.09 & 0.01 & 0.44 \\
\hline $\mathrm{F}_{35}$ & * & $*$ & * & * \\
\hline $\mathrm{F}_{36}$ & $*$ & $*$ & $*$ & $*$ \\
\hline$F_{37}$ & $*$ & $*$ & $*$ & $*$ \\
\hline $\mathrm{F}_{38}$ & $*$ & * & * & $*$ \\
\hline $\mathrm{F}_{39}$ & $*$ & $*$ & $*$ & $*$ \\
\hline $\mathrm{F}_{40}$ & $*$ & $*$ & $*$ & $*$ \\
\hline $\mathrm{F}_{41}$ & $*$ & $*$ & $*$ & $*$ \\
\hline $\mathrm{F}_{42}$ & $*$ & $*$ & * & $*$ \\
\hline $\mathrm{F}_{43}$ & 0.17 & 0.03 & 0.01 & 0.15 \\
\hline $\mathrm{F}_{44}$ & $*$ & $*$ & * & $*$ \\
\hline $\mathrm{PA}_{25}$ & 2.72 & 2.23 & 0.28 & 0.82 \\
\hline
\end{tabular}


Table 3. Analysis of variance of different isolate of Flavobacterium in Auxin production and phosphorous solubilization

\begin{tabular}{cccc}
\hline Alternation sources & Freedom degree & \multicolumn{2}{c}{ Mean square } \\
\hline & & Auxin production & $\begin{array}{c}\text { phosphorous } \\
\text { solubilization }\end{array}$ \\
\cline { 3 - 4 } isolate & 43 & $18 / 717^{* *}$ & $4 / 536^{* *}$ \\
error & 88 & $0 / 115$ & $0 / 004$ \\
\hline
\end{tabular}

**- significant $(\mathrm{p}<0.01)$

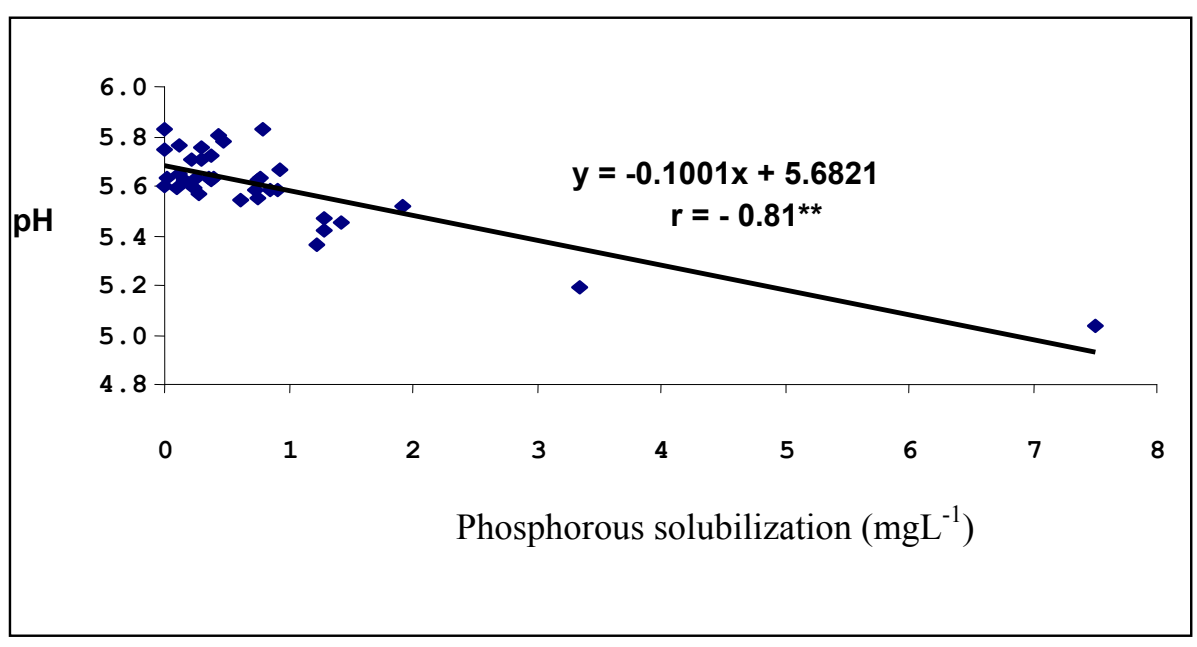

Figure 1. Correlation between Phosphorous solubilization and $\mathrm{pH}$ 